University of Nebraska - Lincoln

DigitalCommons@University of Nebraska - Lincoln

\title{
Beta-2-microglobulin haplotypes in U.S. beef cattle and association with failure of passive transfer in newborn calves
}

\author{
Michael L. Clawson \\ USDA-ARS, Mike.Clawson@usda.gov \\ Michael P. Heaton \\ USDA-ARS, mike.heaton@usda.gov \\ Carol G. Chitko-McKown \\ USDA-ARS, carol.chitkomckown@ars.usda.gov \\ James M. Fox \\ USDA-ARS \\ Timothy P. L. Smith \\ USDA-ARS, tim.smith@ars.usda.gov
}

See next page for additional authors

Follow this and additional works at: https://digitalcommons.unl.edu/hruskareports

Clawson, Michael L.; Heaton, Michael P.; Chitko-McKown, Carol G.; Fox, James M.; Smith, Timothy P. L.; Snelling, Warren M.; Keele, John W.; and Laegreid, William W., "Beta-2-microglobulin haplotypes in U.S. beef cattle and association with failure of passive transfer in newborn calves" (2004). Roman L. Hruska U.S. Meat Animal Research Center. 315.

https://digitalcommons.unl.edu/hruskareports/315

This Article is brought to you for free and open access by the U.S. Department of Agriculture: Agricultural Research Service, Lincoln, Nebraska at DigitalCommons@University of Nebraska - Lincoln. It has been accepted for inclusion in Roman L. Hruska U.S. Meat Animal Research Center by an authorized administrator of DigitalCommons@University of Nebraska - Lincoln. 


\section{Authors}

Michael L. Clawson, Michael P. Heaton, Carol G. Chitko-McKown, James M. Fox, Timothy P. L. Smith, Warren M. Snelling, John W. Keele, and William W. Laegreid 


\title{
Mammälian \\ G
}

\section{Beta-2-microglobulin haplotypes in U.S. beef cattle and association with failure of passive transfer in newborn calves}

\author{
Michael L. Clawson, Michael P. Heaton, Carol G. Chitko-McKown, James M. Fox, \\ Timothy P.L. Smith, Warren M. Snelling, John W. Keele, William W. Laegreid
}

United States Department of Agriculture, Agricultural Research Service, U.S. Meat Animal Research Center (MARC), Spur 18D, P.O. Box 166, Clay Center, Nebraska 68933, USA

Received: 23 July 2003 / Accepted: 29 October 2003

\begin{abstract}
Failure of passive transfer (FPT) is a condition in which neonates do not acquire protective serum levels of maternal antibodies. A principal component of antibody transport is the neonatal receptor for the Fc portion of immunoglobulin, a heterodimer of a MHC-1 alpha-chain homolog (FCGRT) and beta2-microglobulin (B2M). Previously, two FCGRT haplotypes were associated with differences in immunoglobulin $\mathrm{G}$ (IgG) passive transfer in cattle (Laegreid et al. (2002) Mamm Genome 13, 704-710). The present study had two objectives: first, to characterize the $B 2 M$ haplotype structure in a diverse group of U.S. beef cattle, and second, to evaluate those haplotypes for association with either high or low serum IgG levels in newborn calves. Twelve single nucleotide polymorphisms (SNPs), assorted into eight haplotypes, were identified by sequencing regions of $B 2 M$ exons II and IV in a multi-breed panel of 96 beef cattle. Calves homozygous for one of the eight haplotypes $(B 2 M 2,2)$ were at increased risk of FPT (odds ratio $=10.60, \mathrm{CI}_{95 \%} 2.07-54.24, p=0.005$ ) . These results indicate that this haplotype is in linkage disequilibrium with genetic risk factors affecting passive transfer of IgG in beef calves, an important determinant of neonatal calf morbidity and mortality.
\end{abstract}

Placental transfer of immunoglobulin does not occur in cattle (Smith and Little 1922; Mikulska et al. 2000). Calves obtain maternal antibodies solely from colostrum, the immunoglobulin $\mathrm{G}(\mathrm{IgG})$ and protein-

Correspondence to: M.L. Clawson; E-mail: clawson@email.marc. usda.gov rich milk produced near parturition (Butler 1974; Stott et al. 1976, 1979a). Maternal IgG is transported across the neonatal intestinal epithelium within the first $24 \mathrm{~h}$ of life, travels through the lymphatics, and enters blood circulation via the thoracic duct (Blood and Radostits 1989; Besser and Gay 1994). Failure of passive transfer (FPT) results from the reduced transfer of IgG to neonatal serum.

A number of factors contribute to FPT, including seasonality (Gay et al. 1965, 1983; McEwan et al. 1970), time of colostrum ingestion after birth (Stott et al. 1979b), prolonged birth (Szenei 1983; Besser et al. 1990; Weaver et al. 2000), housing conditions (with or without dam) (Stott et al. 1979c), and genetics (Norman et al. 1981; Muggli et al. 1987; Vann et al. 1995; Laegreid et al. 2002). Calves affected with FPT have increased morbidity and mortality rates (Wittum and Perino 1995). Thus, FPT represents a significant risk to the health of calves.

In mammals, the neonatal receptor for the Fc portion of IgG (FcRn) has prominent maternal and neonatal roles in IgG transfer. In neonatal rodents, evidence suggests that FcRn binds IgG on the luminal plasma membrane of intestinal epithelium and mediates the transcytosis of IgG to the basolateral surface (Rodewald and Kraehenbuhl 1984; Israel et al. 1995). In murine lactating mammary glands, FcRn appears to function as a recycling receptor transporting IgG away from the milk glands (Cianga et al. 1999|. In sheep, immunohistological evidence suggests that FcRn is differentially localized in mammary acinar epithelial cells before and after parturition (Mayer et al. 2002). In cattle, expression of FcRn genes has been detected in lactating mammary glands (Adamski et al. 2000; Kacskovics et al. 2000). In bovine neonates, IgG and other constituents of colostrum are transported across the intestine by nonselective pinocytosis (Besser and Gay 1985). 
Although specific transport mechanisms for IgG absorption by neonates have not been described, the biology of FcRn in other species suggests it may have critical transport roles in either the dam or the calf.

FcRn consists of a heterodimer of two different polypeptides (Simister and Mostov 1989; Simister et al. 1997); a class 1 major histocompatibility complex (MHC-I) $\alpha$-chain homolog encoded by FCGRT on bovine Chr 18 (Laegreid et al. 2002), and $\beta_{2} M$ on bovine Chr 10 (Band et al. 2000). Previous work has shown that two FCGRT haplotypes, one in dams and one in calves, are negatively associated with levels of IgG concentration in calf serum (Laegreid et al. 2002). Because $\beta_{2} M$ is also an integral component of the FcRn heterodimer, this gene represents a plausible candidate locus for evaluating haplotype markers for association with FPT. Association mapping (or linkage disequilibrium [LD] mapping) makes use of the haplotype "block" structure in a particular genomic region of affected and control individuals. A haplotype block is a genomic region defined by minimal evidence of recombination in the population of interest (Gabriel et al. 2002). This study describes the identification and frequency of eight $\beta_{2} M$ haplotypes in U.S. beef cattle and evaluates their association with neonatal serum IgG concentration.

\section{Materials and methods}

Animal populations. Five DNA panels were used in this study. The U.S. Meat Animal Research Center (MARC) Beef Cattle Diversity Panel 2.1 (MBCDP2.1; Heaton et al. 2001) is composed of DNA from 92 bulls collectively representing 16 popular beef breeds and four Holstein bulls and was used to determine the genetic diversity of $\beta_{2} M$ haplotypes in U.S. breeds. The MARC Purebred Angus Panel 1.4 (MPAP1.4) is composed of DNA from 192 purebred Angus cattle sampled from seven herds in four Midwestern States and was used to sample $\beta_{2} M$ haplotype diversity in a large population of Angus cattle. The MARC reference population panel (Bishop et al. 1994) is composed of DNA from 313 related individuals with known pedigrees and was used to validate single nucleotide polymorphism (SNP) segregation. The MARC artiodactyl panel 2.0 (MASP2.0; Laegreid et al. 2002) is composed of DNA from 92 artiodactyl individuals representing 14 nonbovine species and was used to determine the ancestral state of bovine SNPs and haplotypes. The DNA panel used for the FPT and high passive transfer (HPT) case-control study (Laegreid et al. 2002) is composed of germplasm from 16 beef breeds including MARC II and MARC III composite breeds.
Calves born in the spring and fall of 2000 were used for this study. Each case animal was matched with two control animals by birth date, sex, and herd. Blood was collected from calves $24 \mathrm{~h}$ after birth for the measurement of serum IgG concentration and DNA extraction as previously described $(\mathrm{n}=608$ cow-calf pairs; Laegreid et al. 2002).

Primer design, DNA amplification, and sequencing. Human and bovine $\beta_{2} M$ sequences were obtained from GenBank (http://www.ncbi.nlm.nih. gov) and The Institute for Genomic Research (TIGR; http://www.tigr.org). Alignments of $\beta_{2} M$ sequence from human genomic DNA, cDNA, and bovine cDNA were constructed in Vector NTI Suite 7.0 (InforMax, Inc. Bethesda, Md.) and used to predict regions of bovine coding sequences (CDS) and intron/ exon boundaries in cDNA. Polymerase chain reaction (PCR) primers were designed by using Oligo 6.0 software (Molecular Biology Insights, Cascade, Colo.) and were purchased from commercial vendors. Regions of $\beta_{2} M$ exon II (BTAB2MDS4) and exon IV (BTAB2MDS3) were selected for PCR amplification based on preliminary experiments of primer performance. Amplicons from the multi-breed diversity panel were sequenced with BigDye terminator chemistry on an ABI 3700 capillary sequencer (PE Applied Biosystems, Boston, Mass.) according to the manufacturer's protocols. PCR products were sequenced with either the amplification primers or primers nested within the amplicon (Table 1). Additional amplification primers nested within BTAB2MDS4 and BTAB2MDS3 were designed and used for automated genotyping to decrease the likelihood of having an undetected SNP disrupt amplification of alleles. Duplex PCR reactions for automated genotyping consisted of $10 \mu \mathrm{L}$ reactions containing 5 ng genomic DNA, 0.21 units of HotStarTaq (Qiagen, Valencia, Calif.), $2.5 \mathrm{mM} \mathrm{MgCl}_{2}, 200$ $\mu \mathrm{M}$ dNTPs, and $0.2 \mu \mathrm{M}$ of primers. PCR conditions were as follows: $94^{\circ} \mathrm{C}$ for $15 \mathrm{~min}, 45$ cycles of $94^{\circ} \mathrm{C}$ for $20 \mathrm{~s}, 58^{\circ} \mathrm{C}$ for $30 \mathrm{~s}, 72^{\circ} \mathrm{C}$ for $1 \mathrm{~min}$, and a final incubation at $72^{\circ} \mathrm{C}$ for $3 \mathrm{~min}$. Amplifications were performed in either a PTC-200 or PTC-220 dyad thermocycler (MJ Research, Watertown, Mass.). The samples were stored at $4^{\circ} \mathrm{C}$ after PCR until use.

SNP and haplotype analyses. Sequences from the 96 animals of the multi-breed diversity panel were aligned and analyzed with Phred and Phrap (Ewing and Green 1998; Ewing et al. 1998), Polyphred 3.0, and Consed 8.0 (Nickerson et al. 1997) software. Animals with homozygous genotypes or one heterozygous site were unambiguously assigned $\beta_{2} M$ haplotypes. Amplicons from individuals with 


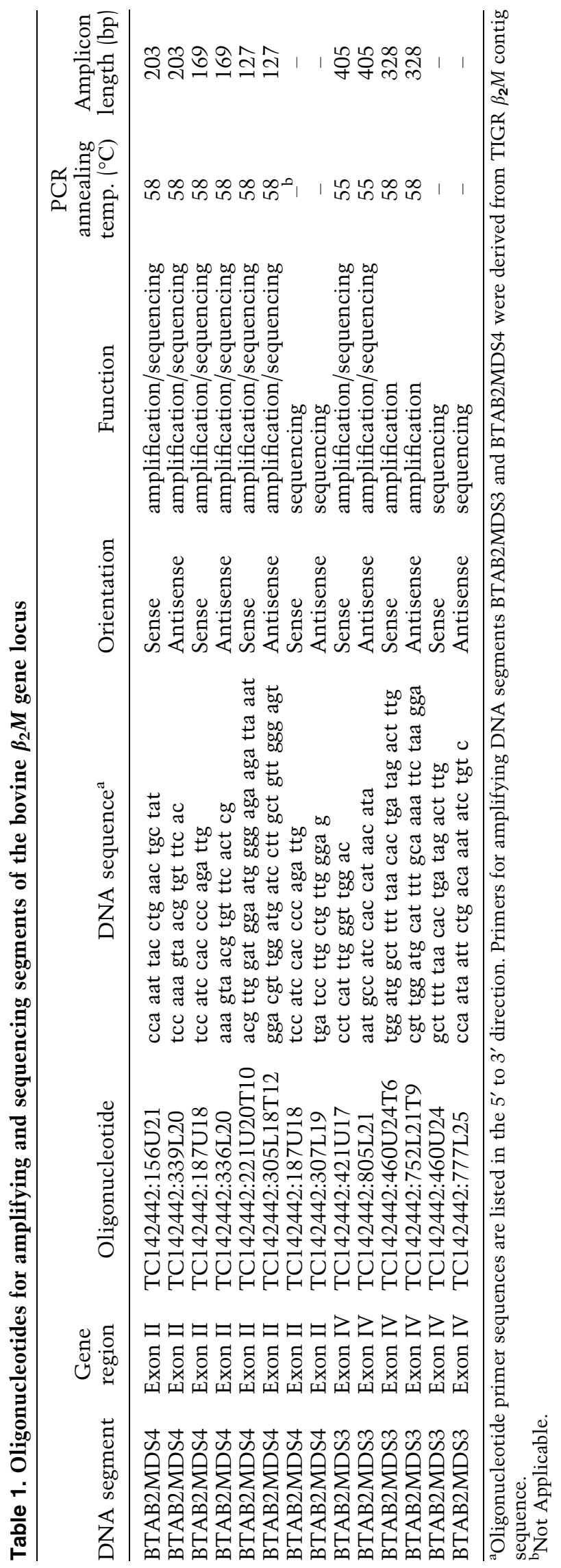

more than one heterozygous site were ligated with plasmid DNA (Topo TA cloning vector 2.1) and transformed into chemically competent cells (Topo $\left.\mathrm{F}^{\prime}\right)$ (Invitrogen, Carlsbad, Calif.) to unambiguously define haplotype phase. PCR and cloning were performed in triplicate for each animal tested. $\beta_{2} M$ haplotype relationships were analyzed with a median-joining network algorithm (Bandelt et al. 1999) in Network 3.1.0.1 (www.fluxus-engineering.com).

\begin{abstract}
Matrix-assisted laser desorption-ionization time-of-flight mass spectrometry (MALDI-TOF MS) genotyping. SNPs identified by sequence analysis were verified by homogeneous MassEXTEND (hME) MALDI-TOF MS genotyping (Sequenom, Inc., San Diego, Calif.). Five multiplex reactions were designed to genotype 12 SNP loci (available upon request). Post-PCR procedures, including unincorporated dNTP digestion, hME reaction preparation and thermocycling, and the purification of hME reactions were conducted according to the manufacturer's instructions. Analytes were arrayed onto silicon chips (Sequenom, Inc.), and MALDI-TOF MS was conducted with an array mass spectrometer (Bruker Daltonics Inc., Billerica, Mass.). Resulting genotypes were stored in a relational database (Oracle, Inc., Redwood City, Calif.) with proprietary software (Sequenom, Inc.).
\end{abstract}

Linkage mapping. Haplotype combinations of individuals in the MARC reference population were inferred from genotypes and based on the known haplotypes identified in MBCDP2.1. These haplotype data were used to verify the location of $\beta_{2} M$ on bovine Chr (BTA) 10 and to estimate its position within the linkage group. The $\beta_{2} M$ marker was mapped by using a perl (www.perl.com) interface to CRI-MAP version 2.4 (Green et al. 1990). Assignment to a linkage group was accomplished via the TWOPOINT option to determine associations between the $\beta_{2} M$ marker and a subset of previously mapped markers representing all chromosomes. Marker position in the assigned linkage group was determined by multi-point FIXED evaluations with the $\beta_{2} M$ marker placed in each possible position within the linkage group. Phase likelihood was determined with CHROMPIC to identify unlikely genotypes. Additional mapping information is available in the MARC cattle genome database (www.marc.usda.gov).

\section{Evaluation of $\beta_{2} M$ haplotypes for association with high or low neonatal serum IgG} levels. Neonatal serum IgG concentrations were measured as previously described (Laegreid et al. 2002). Briefly, calf blood was drawn 24-48 h after 


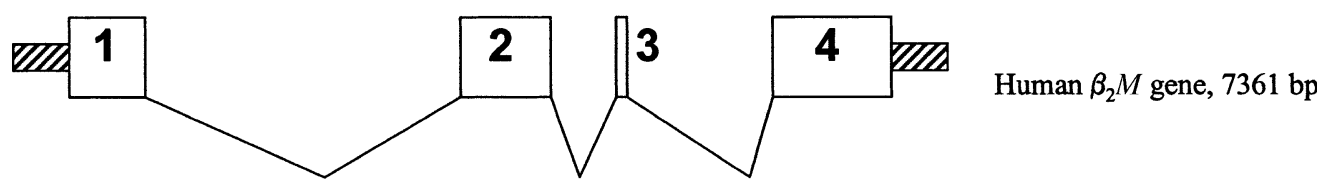

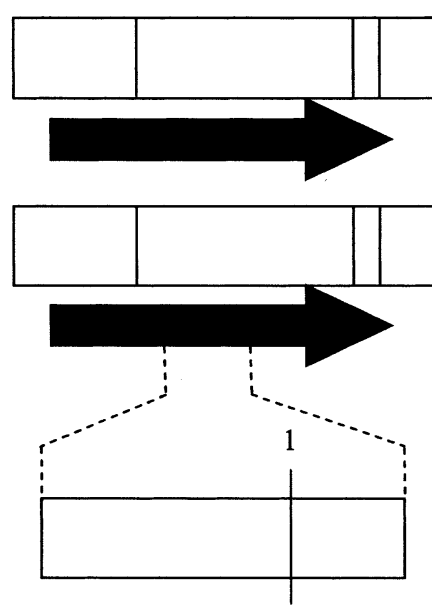

BTAB2MDS4 $203 \mathrm{bp}$

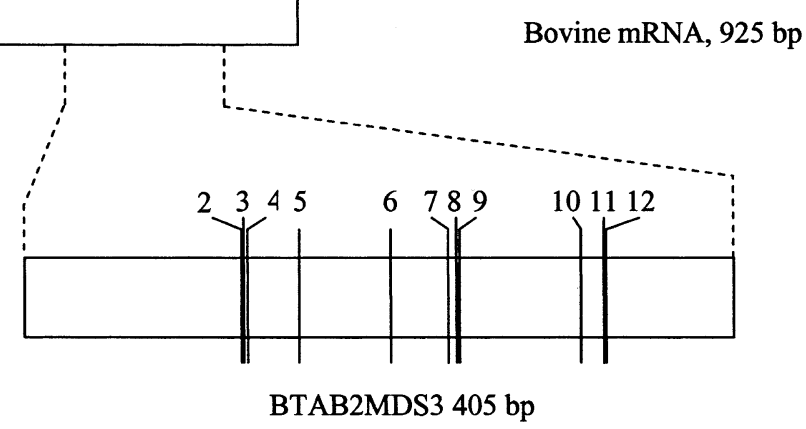

Fig. 1. Physical map of $\beta_{2} M$. Physical maps of human genomic $\beta_{2} M$ DNA sequence (GenBank accession NT_030828), human $\beta_{2}$ M mRNA (GenBank accession AB021288), bovine consensus $\beta_{2} M$ mRNA available from TIGR, and two PCR amplicons, (BTAB2MDS4, GenBank accession AY325772 and BTAB2MDS3, GenBank accession AY325771). $\beta_{2} M$ exons, introns, and coding sequence are represented by unfilled rectangles, thin lines, and solid black arrows respectively. The hatched rectangles represent intergenic DNA. Dashed lines indicate genomic regions of $\beta_{2} M$ amplified with PCR. Numbered vertical lines on BTAB2MDS4 and BTAB2MDS3 represent the location of SNPs AH27-1 through AH27-12.

birth, and serum IgG concentration was determined by radial immunodiffusion by using commercial kits (VMRD, Inc., Pullman, Wash.). Calves with serum IgG concentrations greater than $7,781 \mathrm{mg} / \mathrm{dL}$ (highest $5^{\text {th }}$ percentile) were characterized as having HPT. Calves with serum IgG concentrations less than $1,562 \mathrm{mg} / \mathrm{dL}$ (lowest $5^{\text {th }}$ percentile) were defined as having FPT. Calf and dam genotypes were compared to ensure they were consistent with rules of Mendelian inheritance. Cow/calf pairs with incompatible genotypes were considered either mislabeled or misparented and excluded from the FPT panel. Pearson chi-square $\left[\chi^{2}\right]$ was used to test for differences in the distribution of $\beta_{2} M$ haplotypes between cases and controls in models of dominance, overdominance, additive and recessive inheritance. Association of specific $\beta_{2} M$ haplotypes with FPT and HPT was evaluated by multiple logistic regression, with the most common haplotype in the test population used as the reference condition. Pearson chi-square was used to determine the goodness-of-fit for the models.

\section{Results}

$\beta_{2} M$ SNP identification and haplotype diversity. To identify SNP markers in the $\beta_{2} M$ gene locus that may be in LD with polymorphisms influencing IgG passive transfer, two PCR amplicons were sequenced from 96 bulls of a multi-breed panel (Fig. 1). Consensus DNA sequence from these amplicons was $100 \%$ identical with consensus Bos taurus $\beta_{2} M$ sequence available at the TIGR website, indicating that both amplicons were derived from bovine $\beta_{2} M$ genomic DNA. A comparison of the individual $\beta_{2} M$ DNA sequences revealed 12 polymorphic sites. Eleven SNPs were identified in the 3' untranslated region (UTR) and one in the coding region of exon II (S85, synonomous). Alleles from one set of five SNPs (AH27-2, 4, 5, 11, 12) were in perfect LD (phase) in all animals from the multi-breed panel (Table 2). Similarly, alleles from two other SNPs, AH27-7 and 9, were in perfect LD in the same panel of animals. Because the set of SNP alleles present on a DNA segment of a single chromosome defines a haplotype allele, and a significant proportion of the SNP alleles were in perfect LD, this set of 12 markers contains redundant coverage of haplotype diversity within the $\beta_{2} M$ locus. Eight distinct $\beta_{2} M$ haplotypes were observed in the multi-breed diversity panel (Table 3 ).

Rooted haplotype relationships of $\beta_{2} M$. Binomial statistics predict 13 haplotypes for a set of 12 biallelic SNPs where recombination has not eroded LD. Analysis of eight bovine $\beta_{2} M$ haplotypes 


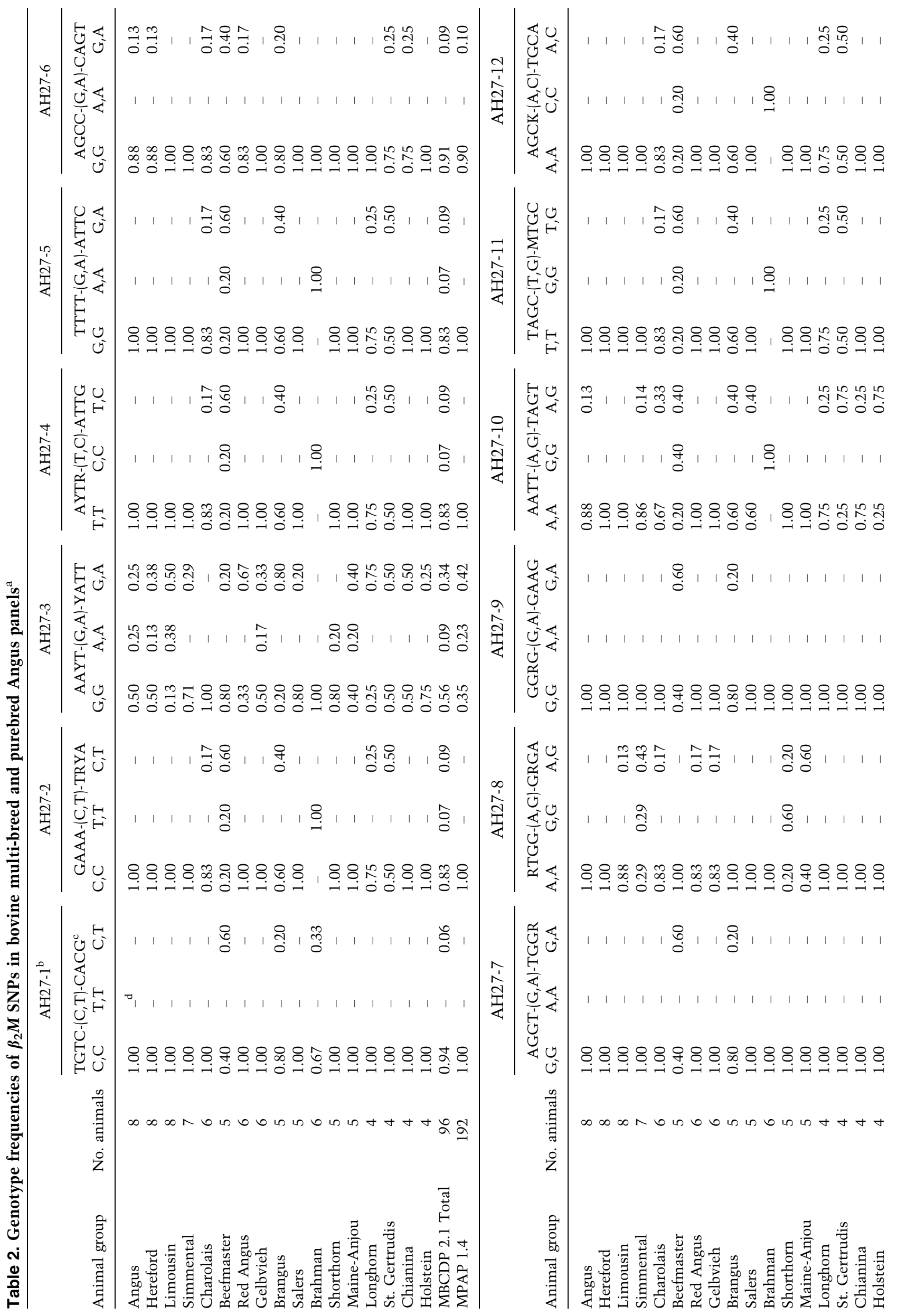



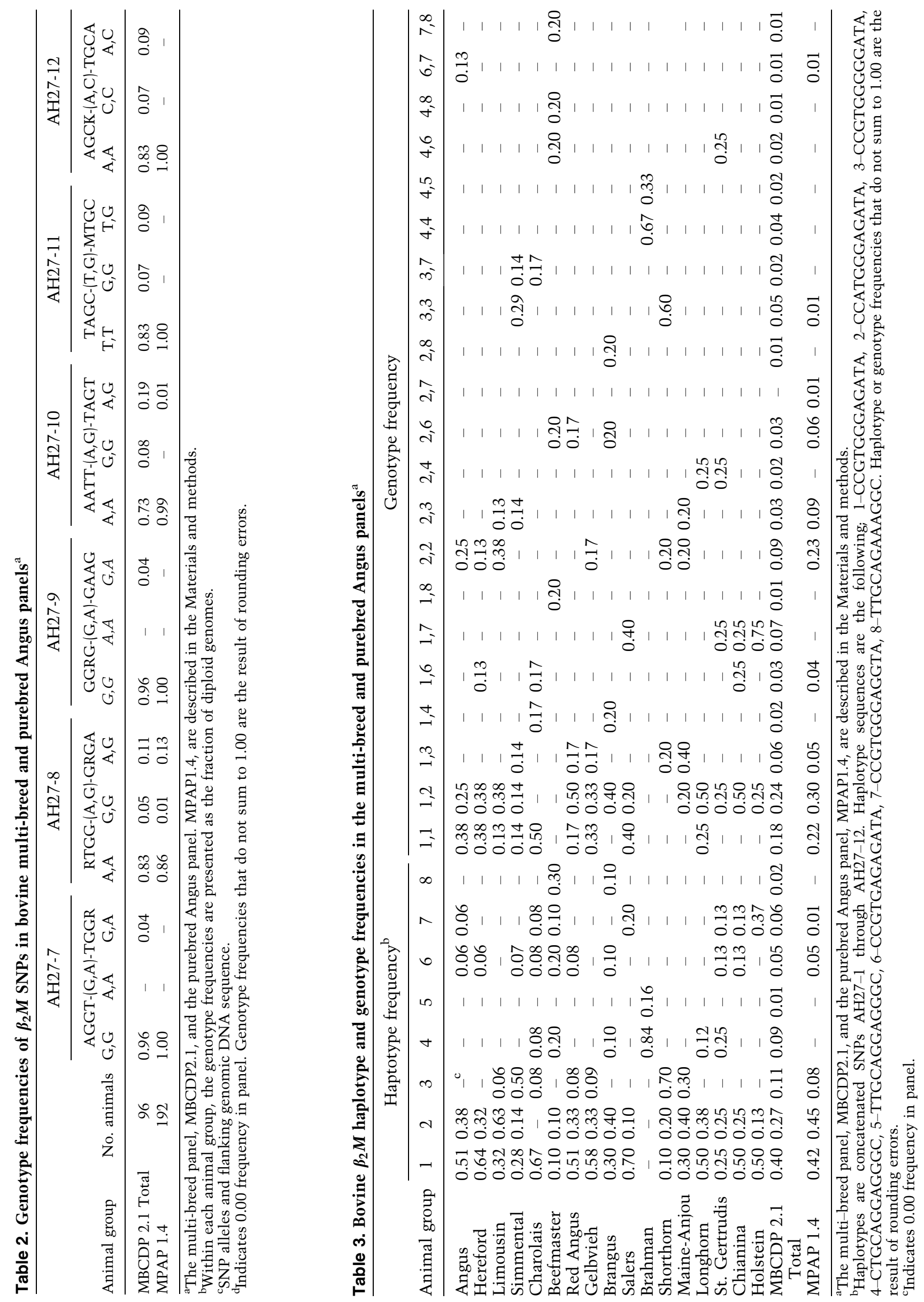


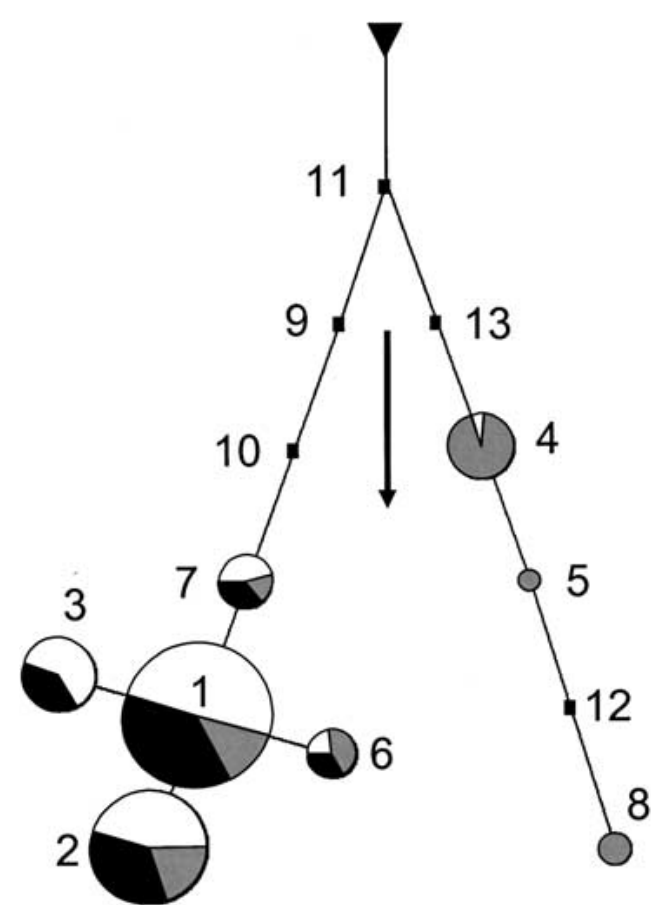

Fig. 2. Rooted haplotype relationships of bovine $\beta_{2} M$. Circles represent extant bovine $\beta_{2} M$ haplotypes identified in this study. The circle areas are proportional to haplotype frequency in the multi-breed cattle panel. The proportion of haplotypes contributed by British or Continental germplasm is indicated by areas of black or white within the circles respectively. The shaded areas indicate the proportion of haplotypes contributed by germplasm influenced by Bos indicus breeds. Black rectangles represent bovine $\beta_{2} M$ haplotypes predicted to have arisen, but not observed in the multi-breed cattle panel. The black triangle represents a haplotype observed in bighorn sheep, mountain goat, and sheep. All non-bovine alleles were monomorphic at the sites corresponding to the 12 bovine SNPs. The arrow indicates the proposed direction of time.

produced an unrooted tree with 13 nodes (data not shown). To estimate $\beta_{2} M$ haplotype ancestry in cattle, related species from the MASP2.0 panel were sequenced, and their allelic state was scored at the corresponding 12 SNP sites. Complete haplotype information was obtained for bison, gaur, water buffalo (haplotype 9), bighorn sheep, domestic sheep, and mountain goat (triangle haplotype) (Fig. 2). An analysis of the eight bovine and two MASP2.0 panel haplotypes with the median-joining algorithm identified two major bovine lineages, five theoretical $\beta_{2} M$ haplotypes, and an ovine specific lineage. Because haplotype 9 was observed in bison, gaur, and waterbuffalo, and was predicted as a node of one cattle lineage, this haplotype may have been present in a recent ancestor common to these species. The median-joining tree indicates that haplotype 11 is the most likely ancestral haplotype of the two bovine lineages because it is arranged between haplotypes 9,
13, and the ovine specific haplotype (Fig. 2, triangle). Conversely, bovine haplotypes present on the terminal nodes of the tree $(2,3,6,8)$ are predicted to represent younger mutations with regard to their haplotype lineages. Five of the observed haplotypes $(1,2,3,6,7)$ are present in one major lineage and in breeds influenced primarily by $B$. taurus germplasm. The three remaining observed haplotypes $(4,5,8)$ are present in the other major lineage and were prevalent in breeds influenced by $B$. indicus germplasm.

Linkage mapping. Two-point analyses detected significant LD (lod $>3.0)$ between the $\beta_{2} M$ marker and markers previously mapped to BTA 10 . Significant LD with markers mapped to other linkage groups was not identified. The strongest associations (indicated by high lod scores and low recombination fractions) were with markers near the telomere. Multipoint analyses of BTA 10 indicates the most likely placement of the $\beta_{2} M$ marker is at the most telomeric marker, $107 \mathrm{cM}$ from the centromere with 194 informative meiosis. Inserting the $\beta_{2} M$ marker into positions other than the most distal one substantially decreases likelihood of the map (lod differences of -10 to -134$)$.

Association of $\beta_{2} M$ haplotypes with IgG concentration. Six $\beta_{2} M$ haplotypes were observed in case and control animals of the FPT test group (Table 4) and thus were available for an evaluation of their association with FPT. The frequency of $\beta_{2} M$ genotype 2,2 was greater than sevenfold higher in case calves than in the control calves. Unconditional logistic regression analysis of a recessive haplotype inheritance pattern showed a significant association of case calves scored with the $\beta_{2} M$ genotype 2,2 and FPT (Pearson's chi-square $\left[\chi^{2}\right]=4.61, p=0.03$, odds ratio $[$ O.R. $]=10.60,95 \%$ confidence interval of O.R. $\left[\mathrm{CI}_{95 \%}\right]=2.07$ to $\left.54.24, p=0.005\right)$. Goodness-of-fit of the model was adequate by Pearson $\chi^{2}$. No HPT associations were detected with the five $\beta_{2} M$ haplotypes available for analysis.

\section{Discussion}

Neonatal calves with FPT are at significant risk of morbidity and mortality from infectious disease (Smith and Little 1922; McGuire et al. 1976). This report describes the structure of $\beta_{2} M$ haplotypes in a diverse group of U.S. beef cattle and the association of one $\beta_{2} M$ haplotype with FPT in neonatal calves. The identification of each of the $12 \beta_{2} M$ SNPs and their haplotypes was validated by DNA sequencing, MALDI-TOF MS, and segregation analysis. Further evidence of marker quality was demonstrated in 


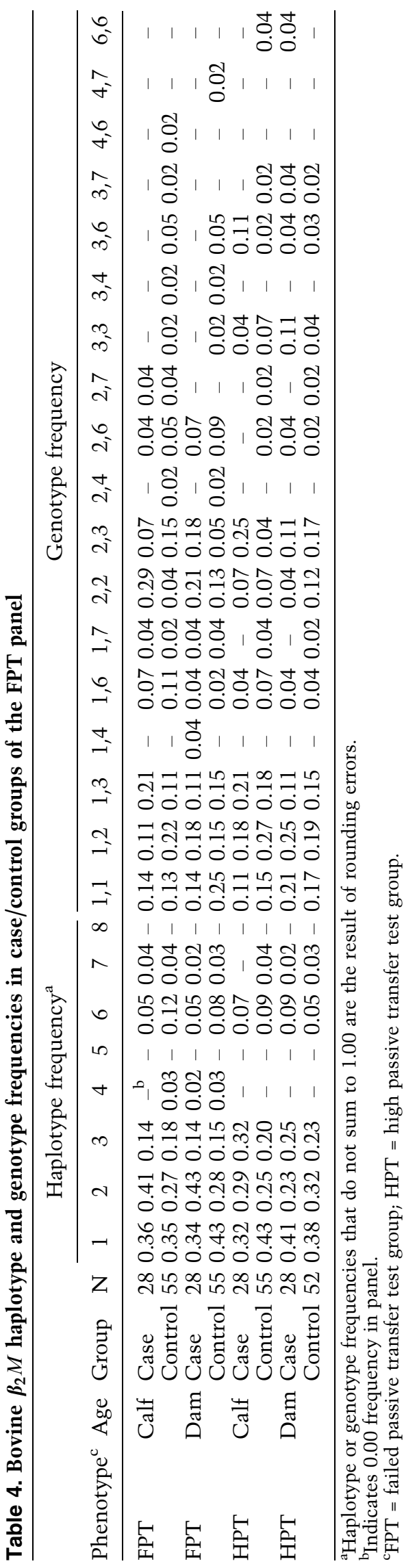

multi-point linkage analysis by the gene locus map position approximately $107 \mathrm{~cm}$ from the centromere of BTA 10, the chromosome previously predicted (Band et al. 2000). Because of the relatively high LD among the SNP alleles, the eight $\beta_{2} M$ haplotypes appear to represent the majority of diversity for this region of the genome in U.S. beef cattle populations.

The association of $\beta_{2} M$ genotype 2,2 with FPT indicates that a genomic block containing $\beta_{2} M$ has one or more genetic risk factors affecting IgG transfer. Haplotype 2 is defined by an SNP allele within the 3'UTR (exon 4; AH27-3), and the possibility that it directly effects passive transfer cannot be excluded. Regardless of the precise location of alleles influencing FPT, AH27-3 represents a useful marker for predicting FPT since calves that inherit the $\beta_{2} M$ genotype 2,2 are 10 times more likely to fail passive transfer than calves with other $\beta_{2} M$ genotypes. The significance of this finding is increased by the observation that the 2,2 genotype was found in $9 \%$ of a diverse group of U.S. beef cattle.

Haplotype alleles for each gene of the neonatal Fc receptor (FCGRT and $\beta_{2} M$ ) have now been evaluated for association with FPT. These alleles reside on different bovine chromosomes and therefore represent genetic risk associated with FPT from different haplotype blocks. With regards to FCGRT, dams with one or more copies of FCGRT haplotype 3 were previously shown to be 3.8 times more likely to have a calf with FPT (Laegreid et al. 2002). This raises the question: if dams with FCGRT haplotype 3 give birth to calves with two copies of $\beta_{2} M$ haplotype 2 , what are the odds that the calves will fail passive transfer? Only three dam/calf pairs in the present study met this criterion, and thus there were not enough cases to be statistically significant. However, all three of the calves were cases of FPT. Consequently, a cumulative effect between haplotype alleles in the FCGRT and $\beta_{2} M$ genomic regions cannot be ruled out.

Prospective studies designed to determine the attributable risk and predictive value of both $\beta_{2} M$ and FCGRT haplotype markers are needed to help determine how best to manage these alleles in production settings. Managing alleles with significant predictive value for FPT may facilitate the reduction of infectious diseases in beef cattle.

\section{Acknowledgments}

The authors are indebted to Gennie Schuller-Chavez, who provided outstanding technical assistance to this project. We thank Drs. J.L. Bono, B.A. Freking, J.E. Keen, and T.S. Sonstegard for critical comments regarding this manuscript. We also 
thank Jacky Carnahan, Linda Flathman, Renee Godtel, Bob Lee, Steve Simcox, and Tammy Sorenson for expert technical support; Colette Adney, Phil Anderson, Randy Bradley, Bucky Herman, and Jim Wray for database and network support; Sherry Kluver and Joan Rosch for secretarial assistance; Gordon Hays and the MARC cattle crew for their assistance in the collection of FPT case and control samples.

Names are necessary to accurately report the available results; however, the USDA neither guarantees nor warrants the standard of the product, and the use of names by USDA implies no approval of the product to the exclusion of others that may also be suitable.

\section{References}

1. Adamski FM, King AT, Demmer J (2000) Expression of the Fc receptor in the mammary gland during lactation in the marsupial Trichosurus vulpecula (brushtail possum). Mol Immunol 37, 435-444

2. Band MR, Larson JH, Rebeiz M, Green CA, Heyen DW, et al. (2000) An ordered comparative map of the cattle and human genomes. Genome Res 10, 1359-1368

3. Bandelt HJ, Forster P, Rohl A (1999) Median-joining networks for inferring intraspecific phylogenies. Mol Biol Evol 16, 37-48

4. Besser TE, Gay CC (1985) Septicemic colibacillosis and failure of passive transfer of colostral immunoglobulins in calves. Vet Clin N Am Food Anim Pract 1, 445-459

5. Besser TE, Gay CC (1994) The importance of colostrum to the health of the neonatal calf. Vet Clin N Am Food Anim Pract 10, 107-117

6. Besser TE, Szenei O, Gay CC (1990) Decreased colostral immunoglobulin absorption in calves with postnatal respiratory acidosis. J Am Vet Med Assoc 196, 1239-1443

7. Bishop MD, Kappes SM, Keele JW, Stone RT, Sunden SL, et al. (1994) A genetic linkage map for cattle. Genetics 136, 619-639

8. Blood DC, Radostits OM (1989) Neonatal infection. In: Blood DC, Radostits OM, eds. Veterinary medicine, Baillière Tindall. Philadelphia, pp. 107-121

9. Butler JE (1974) Immunoglobulins of the mammary secretions. In: VR Smith, ed. Lactation: a comprehensive treatise. New York: Academic Press, pp. 217-252

10. Cianga P, Medesan C, Richardson JA, Ghetie V, Ward ES (1999) Identification and function of neonatal Fc receptor in mammary gland of lactating mice. Eur J Immunol 29, 2515-2523

11. Ewing B, Green P (1998) Base-calling of automated sequencer traces using phred. II. Error probabilities. Genome Res 8, 186-194

12. Ewing B, Hillier L, Wendl MC, Green P (1998) Basecalling of automated sequencer traces using phred. I. Accuracy assessment. Genome Res 8, 175-185
13. Gabriel SB, Schaffner SF, Nguyen H, Moore JM, Roy J, et al. (2002) The structure of haplotype blocks in the human genome. Science 296, 2225-2229

14. Gay CC, Fisher EW, McEwan AD (1965) Seasonal variations in gamma globulin levels in neonatal market calves. Vet Rec 77, 994

15. Gay CC, McGuire TC, Parish SM (1983) Seasonal variation in passive transfer of immunoglobulin G1 to newborn calves. J Am Vet Med Assoc 183, 566-568

16. Green P, Falls K, Crooks S (1990) Documentation for CRI-MAP version 2.4. (St. Louis, Mo.: Washington University School of Medicine)

17. Heaton MP, Chitko-McKown CG, Grosse WM, Keele JW, Keen JE (2001) lnterleukin-8 haplotype structure from nucleotide sequence variation in commercial populations of U.S. beef cattle. Mamm Genome 12, 219-226

18. Israel EJ, Patel VK, Taylor SF, Marshak-Rothstein A, Simister NE (1995) Requirement for a beta 2-microglobulin-associated Fc receptor for acquisition of maternal IgG by fetal and neonatal mice. J Immunol 154, 6246-6251

19. Kacskovics I, Wu Z, Simister NE, Frenyo LV, Hammarstrom L (2000) Cloning and characterization of the bovine MHC class I-like Fc receptor. J Immunol 164, 1889-1897

20. Laegreid WW, Heaton MP, Keen JE, Grosse WM, Chitko-McKown CG, et al. (2002) Association of bovine neonatal Fc receptor alpha-chain gene (FCGRT) haplotypes with serum IgG concentration in newborn calves. Mamm Genome 13, 704-710

21. Mayer B, Zolnai A, Frenyo LV, Jancsik V, Szentirmay $\mathrm{Z}$, et al. (2002) Redistribution of the sheep neonatal Fc receptor in the mammary gland around the time of parturition in ewes and its localization in the small intestine of neonatal lambs. Immunology 107, 288-296

22. McEwan AD, Fisher EW, Selman IE (1970) Observations on the immune globulin levels of neonatal calves and their relationship to disease. J Comp Pathol 80, 259-265

23. McGuire TC, Pfeiffer NE, Weikel JM, Bartsch RC (1976) Failure of colostral immunoglobulin transfer in calves dying from infectious disease. J Am Vet Med Assoc 169, 713-718

24. Mikulska JE, Pablo L, Canel J, Simister NE (2000) Cloning and analysis of the gene encoding the human neonatal Fc receptor. Eur J Immunogenet 27, 231-240

25. Muggli NE, Hohenboken WD, Cundiff LV, Mattson DE (1987) Inheritance and interaction of immune traits in beef calves. J Anim Sci 64, 385-393

26. Nickerson DA, Tobe VO, Taylor SL (1997) PolyPhred: automating the detection and genotyping of single nucleotide substitutions using fluorescence-based resequencing. Nucleic Acids Res 25, 2745-2751

27. Norman LM, Hohenboken WD, Kelley KW (1981) Genetic differences in concentration of immunoglobulins G1 and M in serum and colostrum of cows and in serum of neonatal calves. J Anim Sci 53, 1465-1472

28. Rodewald R, Kraehenbuhl J (1984) Receptor-mediated transport of IgG. J Cell Biol 99, 159s-164s 
29. Simister NE, Mostov KE (1989) An Fc receptor structurally related to MHC class I antigens. Nature 337, 184-187

30. Simister NE, Jacobowitz IE, Ahouse JC, Story CM (1997) New functions of the MHC class I-related Fc receptor, FcRn. Biochem Soc Trans 25, 481-486

31. Smith R, Little R (1922) The significance of colostrum to the newborn calf. J Exp Med 36, 181-198

32. Stott GH, Wiersma F, Menefee BE, Radwanski FR (1976) Influence of environment on passive immunity in calves. J Dairy Sci 59, 1306-1311

33. Stott GH, Marx DB, Menefee BE, Nightengale GT (1979a) Colostral immunoglobulin transfer in calves I. Period of absorption. J Dairy Sci 62, 1632-1638

34. Stott GH, Marx DB, Menefee BE, Nightengale GT (1979b) Colostral immunoglobulin transfer in calves. III. Amount of absorption. J Dairy Sci 62, 1902-1907
35. Stott GH, Marx DB, Menefee BE, Nightengale GT (1979c) Colostral immunoglobulin transfer in calves. IV. Effect of suckling. J Dairy Sci 62, 1908-1913

36. Szenei O (1983) Effects of type and intensity of assistance on acid-base balance of newborn calves. Acta Vet Hung 31, 73-79

37. Vann RC, Holloway JW, Carstens GE, Boyd ME, Randel RD (1995) Influence of calf genotype on colostral immunoglobulins in Bos taurus and Bos indicus cows and serum immunoglobulins in their calves. J Anim Sci 73, 3044-3050

38. Weaver DM, Tyler JW, VanMetre DC, Hostetler DE, Barrington GM (2000) Passive transfer of colostral immunoglobulins in calves. J Vet Intern Med 14, 569-577

39. Wittum TE, Perino LJ (1995) Passive immune status at postpartum hour 24 and long-term health and performance of calves. Am J Vet Res 56, 1149-1154 